\title{
Pembentukan Identitas Kaum Waria Kecamatan Bulukumpa
}

\author{
Ibrahim
}

\author{
Darmawan Salman \\ Universitas Hasanuddin Makassar \\ darmawansalmanunhas@gmail.com
}

\author{
Suardi \\ Universitas Muhammadiyah Makassar \\ suardi@unismuh.ac.id
}

\begin{abstract}
ABSTRAK
Masalah utama dalam penlitian ini adalah masalah proses pembentukan identitas waria yang ada di Kecamatan Bulukumpa. Jenis penelitian ini adalah penelitian kualitatif deskriptif, dimana penelitian ini bermaksud untuk memahami fenomena tentang apa yang dialami oleh subjek penelitian, misalnya persepsi, tindakan, prilaku dan lainlain, secara holistik dan dengan cara deskripsi dalam bentuk kata-kata dan bahasa. Prosedur penelitian ini meliputi tahap sebelum ke lapangan, tahap pekerjaan lapangan, tahap analisis data dan tahap penulisan laporan.Hasil penelitian ini menujukkan bahwa proses terbentuknya identitas waria di kompleks pasar Tanete adalah bahwa identitas waria terbentuk karena dengan menjadi waria merupakan cara yang paling tepat untuk memperkenalkan diri mereka kepada lingkungan sosialnya. Dalam hal ini, pamor menjadi waria merupakan media yang paling ampuh dalam menyampaikan pesan (isi hati yang terpendam) untuk diketahui orang lain secara sengaja. Kemudian yang kedua adalah Identitas warita terbentuk darisifat-sifat tertentu yang dimiliki kaum waria di kompleks pasar Tanete yang melihat menjadi waria merupakan takdir dalam kehidupan sosialnya. Kaum waria di Tanete percaya bahwa dengan menjadi waria adalah cara mereka untuk memenuhi kebutuhan aktualisasi diri di masyarakat.
\end{abstract}

Kata Kunci: Pembentukan, Identitas, Waria.

\section{PENDAHULUAN}

Setiap manusia dalam hidupnya akan selalu berkembang dan harus melalui tahaptahap perkembangannya. Akibat dari perkembangan tersebut, manusia akan mengalami perubahan-perubahan, baik fisik maupun psikologisnya. Biladitinjau dari manusia sebagai makhluk holistic, maka perkembangan manusia tidak akan dapat dilepaskan dari interaksi antara unsur biologis, psikologis, dan social. Ketiga unsur ini saling mempengaruhi sebagai satu kesatuan (Maramis, dalam Kurniawati (2003). Dalam kurun waktu perkembangan tersebut,tidak setiap individuakan berkembang sesuai dengan perkembangan fisiknya. Sebagai contoh,tidak semua anak laki-laki akan berkembang menjadi laki-lakisesungguhnya, dan tidak semua anak perempuan akan berkembangmenjadi wanita sesungguhnya. Bisa sajaterjadi, anak laki-laki akan berkembang menjadi waria dan anak perempuan berkembangan menjadi "tomboy". Waria adalah seseorang yang memiliki ketidaksesuaian antara fisik dengan identitas gendernya. 
Mereka merasa bahwa jauh dalam dirinya, biasanyasejak masa kanak-kanak, mereka adalah orang yang berjenis kelamin berbeda dengan dirinya saat ini ((Perroto \& Culkin, 1993).).Adanya ketidaksesuaian itu mengakibatkan waria tidak senang dengan alat kelaminnya dan ingin mengubahnya. Untuk mendukung perubahan tersebut maka waria akan bertingkah laku seperti perempuan dan mengidentifikasikan dirinya sebagai perempuan dengan cara berdandan seperti perempuan (Lidiawati, dalam Kurniawati (2003)).

Menurut peneliti hal ini merupakan sebuah tantangan tersendiri didalam memahami realita yang selama ini melanda kaum pria yang terjebak dalam lingkaran multi identitas.Karena kebanyakan yang terjerumus dalam permainan identitas adalah orang-orang yang mengaku pengikut modernisasi seperti dibidang fashion. Olehnya itu peneliti akan berusaha semaksimal mungkin untuk menyajikan sebuah pengetahuan baru tentang perubahan identitas yang selama ini melanda kaum pria yang seharusnya menjadi pemimpin, terutama didalam keluarga, bukan sebagai pengikut bagi seorang wanita

\section{LANDASAN TEORI}

Manusia adalah mahkluk yang bertanya akan dirinya. Mahkluk yang harusmencari identitas dirinya.Mahkluk dengan kesadaran di manakah seharusnya dia berada.Keadaan tersebut tidak terjadi pada mahkluk-mahkluk lainnya, hewan, tumbuhan, dan lingkungan sekitarnya. Identitas umumnya dimengerti sebagai suatu kesadaran akan kesatuan dan kesinambungan pribadi, suatu kesatuan unik yang memelihara kesinambungan arti masa lampaunya sendiri bagi diri sendiri dan orang lain; kesatuan dan kesinambungan yang mengintegrasikan semua gambaran diri, baik yang diterima dari orang lain maupun yang diimajinasikan sendiri tentang apa dan siapa dirinya serta apa yang dapat dibuatnya dalam hubungan dengan diri sendiri dan orang lain. Identitas diri seseorang juga dapat dipahami sebagai keseluruhan ciri-ciri fisik, disposisi yang dianut dan diyakininya serta daya-daya kemampuan yang dimilikinya. Kesemuanya merupakan kekhasan yang membedakan orang tersebut dari orang lain dan sekaligus merupakan integrasi tahap-tahap perkembangan yang telah dilalui sebelumnya.

Erikson (1989) membedakan dua macam identitas, yakni identitas pribadi dan identitas ego. Identitas pribadi seseorang berpangkal pada pengalaman lansung bahwa selama perjalanan waktu yang telah lewat, kendati mengalami berbagai perubahan, ia tetap tinggal sebagai pribadi yang sama. Identitas pribadi baru dapat disebut identitas Ego kalau identitas itu disertai dengan kualitas eksistensial sebagai subyek yang otonom yang 
mampu menyelesaikan konflik-konflik di dalam batinnya sendiri serta masyarakatnya. Menurut erikson, proses pembentukan identitas berlangsung secara pelan-pelan dan pada awalnya terjadi secara tak sadar dalam inti diri individu. Proses pembentukan identitas yang berangsur-angsur itu sebenarnya sudah dimulai pada periode pertama, yakni periode kepercayaan dasar lawan kecurigaan dasar.

Manusia sebagai pribadi tidak dirumuskan sebagai suatu kesatuan individu saja tanpa sekaligus menghubungkannya dengan lingkungan sekitarnya.Kita tidak dapat membugkusnya ke dalam satu kesatuan individu saja, yang tidak pernah bersinggungan dengan lingkungan.Ketika kita membicarakan identitas di situ juga kita membicarakan kelompok. Buat Verkuyten, gagasan tentang identitas adalah hubungan antara individu dengan lingkungannya (Verkuyten, 2005). Adanya identitas dapat lebih memudahkan manusia menggambar keberadaan sesuatu sehinga dapat memberikan kemudahan manusia untuk bertindak.

Suatu kepribadian akan menjadi kepribadian apabila keseluruhan sistem psikofisiknya temasuk bakat kecakapan dan ciri-ciri kegiatannya menyatakan sebagai kekhasan dirinya dalam penyesuaian dirinya dengan lingkungannya. Kepribadian individu, keahlian individu, ciri-ciri akan dirinya baru akan ketahuan kepribadiannya ketika sudah melakukan interaksi dengan lingkungannya. Individu memerlukan hubungan dengan lingkungan yang menggiatkannya, merangsang perkembangannya, atau memberikan sesuatu yang ia perlukan. Tanpa hubungan, individu bukanlah individu lagi (Gerungan, 2004).

Oetomo (dalam Kurniawati, 2003) menyatakan bahwa dalam perkembangannya waria merupakan "proyek" feminimitas yang artinya suatu proses keadaanmaskulin ke feminim. Waria yang mempunyai tubuh atau fisik laki-laki, mempertontonkan perilaku serta atribut yang halus dari perempuan meskipun pada saat-saat tertentu mereka masih menunjukkan keagresifannya, menunjukkan aksi maskulin dan menganggap penetrator sebagai peranseksualnya.Waria adalah seseorang yang memiliki ketidaksesuaian antara fisikdengan identitas jenis kelaminnya (Perroto \& Culkin, 1993).Kusumayanti (2000) menyatakan wariaatau banci adalah jenis kelamin ketiga, yang memiliki sifat antara pria dan wanita tetapi bukan penggabungan diantara keduanya. Hal tersebut merupakan sebutan awal yang menggambarkan perempuan yang terjebak dalam tubuh lakilaki.Atmojo (dalam Kurniawati, 2003) menyatakan bahwa waria terbagi dalam kelompok kecil :

1) Kaum transeksual 
Mereka yang termasuk dalam kelompok ini mengalami ketidakserasian pada jenis biologis dan jenis kelamin mereka.Ada keinginan dari mereka untukmenghilangkan dan menggantikan alat kelaminnya dan hidup sebagai lawan jenisnya. Untuk langkah awal mereka biasanya menghilangkan ciri fisik laki -lakinya, misal: mengoperasi sebagian dari tubuhnya seperti payudara, dagu, kelopak mata, minimal mereka merasa perlu merias diri dan berpakaian seperti wanita. Kelompok ini memenuhi criteria penderita transeksual.Kaum transvestite

2) Kaum homoseksual penderita transvestismen

Selain mereka yang bersifat maskulin, feminism, atau yang kewanita -wanitaan, atau mereka yang tergolong closed type, terdapat pula homoseksual yang juga menderita transvestisme. Yaitu, mereka yang mendapat kepuasan seksual dari hubungan homosekual dan berpakaian lawan jenis.

\section{3) Kaum opportunitie}

Kelompok ini terdiri dari mereka yang memanfatkan kesempatan.Dimana mereka menjadi waria untuk mencari penghasilan atau nafkah. Jadi tidak terdapat kelainan seperti kelompok sebelumnya.

Dalam teori identitas sosial, seorang individu tidaklah dianggap sebagai individu secara mutlak satu dalam kehidupannya.Individu merupakan bagian dari kelompok tertentu baik disadari maupun tidak disadari. Konsep identitas sosial adalah bagaimana seseorang itu secara sosial dapat didefinisikan.Dalam hal identitas, Identitas itu ada yang diberi, tetapi ada juga yang memang berasal dari proses pencarian. Identitas yang terberi cantohnya saja dalam hal identitas laki-laki dan perempuan.Identitas andi sebagai lakilaki adalah identitas yang sudah terberi sejak lahir, mau tidak mau dia harus menerima itu.Namun demikian, dengan kemajuan teknologi yang ada, identitas yang terberipun bisa diganti dengan identitas yang kita inginkan, misalnya saja yang tadinya andi memiliki identitas laki-laki, namun dia memutuskan untuk merubah alat kelaminnya menjadi perempuan, sehingga identitas andi sekarang adalah perempuan.Penjelasan tersebut sekedar memberikan contoh saja kalau terkadang kitapun tak berhak memilih identitas kita sendiri.Karena manusia sebagai individu tidak bisa melepas keberadaannya dalam masyarakatmaka status identitas kita pun bisa saja datang darioranglain.Ini bisa timbul karena ketika identitas terlahir, lahir pulalah perbedaan yangjuga berupaya memberi identitas kepada orang di luar dirinya.

Manusia bukanlah makhluk yang pasif, menerima begitu saja keberadaan dirinya dan tidak butuh pengenalan diri.Manusia itu adalah makhluk yang dapat mengenal dan 
memikirkan situasi yang ada, melakukan sesuatu, berefleksi, menegaskan, bereaksi, dan berkreasi. Namun demikian, manusia tidak serta merta memilih akan identitasnya berasalkan dari pemikirannya pribadi tanpa terkanan dari luar. Masyarakat pun memberikan andil akan identitasnya. Ini karena identitas berasal dari interaksi individu dengan masyarakat.Dengan interaksi itu dia dapat mengetahui identitas mana yang cocok untuk dirinya.

Identitas sosial juga menghasilkan representasi sosial yang keluar dari individuindividu yang berkumpul serta memiliki pandangan dan emosi yang sama (Doise. 1998,). Representasi sosial dapat didefinisikan sebagai prinsip hubungan simbolik yang terorganisasi.Mereka memperkenalkanletak individu dalam hubungannya dengan objek sosial secara siknifikan.Individu adalah objek yang melekat dalam jaringan relationship mengartikan sosial representasi sebagai kumpulan konsep, statements dan asal penjelasan dalam kehidupan sebagai bagian dari komunikasi inter-individual yang merupakan equivalent dalam kehidupan bermasyarakat, sebagai mitos dan sistem kepercayaan dalam masyarakat tradisional.Representasi sosial juga merupakan konsensus pemahaman yang timbul dari kekacauan diskusi dan komunikasi informal keseharian, sebagai keinginan individu untuk memahami dunia (Hogg \& Abrams, 1988).

\section{METODE PENELITIAN}

Jenis penelitian yang dilakukan penelitian kualitatif yang bertujuan memahami Proses Pembentukan Identitas Kaum Waria (Studi tentang keberadaan kelompok kaum waria di Kecamatan Bulukumpa). Prosedur penelitian terdiri tahap sebelum ke lapangan, tahap pekerjaan lapangan, analisis data, tahap penulisasn laporan, Instrumen penelitian adalah peneliti sendiri dan alat bantu yang lain seperti lembar observasi dan kamera. Informan ditentukan secara purposive sampling, teknik pengumpulan data yaitu observasi, wawancara dan dokumntasi, kemudian dianalisis melalui tahapan pengumpulan data (data collection), reduksi data (data reduction), penyajian datadata display), data yang dikelompokan, penarikan kesimpulan (conclusion) dan menggunakan teknik keabsahan data triangulasi sumber, waktu, dan teknik.

\section{PEMBAHASAN}

Identitas waria terbentuk karena dengan menjadi waria merupakan cara yang paling tepat untuk memperkenalkan diri mereka kepada lingkungan sosialnya. Dalam hal 
ini, pamor menjadi waria merupakan media yang paling ampuh dalam menyampaikan pesan (isi hati yang terpendam) untuk diketahui orang lain secara sengaja. Dimana sesorang yang menjadi waria akan terbebas dari pekerjaan-pekerjaan yang sifatnya kasar dan menguras tenaga, serta sebagai ajang didalam meniti karier yang lebih baik. Upaya untuk memahami diri didapat dari proses identifikasi diri dengan orang lain (waria), tanpa peduli dengan identitas yang sesungguhnya, mereka harus meninggalkan identitas aslinya demi mengejar suatu tujuan, yaitu bagaimana cara memperbaiki kualitas hidup. Karena kebanyakan waria yang bekerja di Tanete adalah membuka salon serta sebagai tukang jahit, dan keuntungan dari pekerjaan tersebut bisa meningkatkan taraf kehidupan dari waria itu sendiri.Hal yang utama dan mendasar bagi mereka yaitu bagaimana mereka hidup sejahtera dan terbebas dari pekerjaan yang tidak menentu serta penghasilan yang rendah, sehingga mereka memilih alternatif yang bisa megantarkan pada kebahagiaan hidup, serta tidak banyak menguras tenaga, cukup dengan kreativitas.sepertinya menjadi waria sudah menjadi kenikmatan tersendiri bagi mereka tanpa harus terikat oleh perbedaan psikis dalam dirinya

Identitas diri juga terbentuk dari sifat-sifat tertentu yang dimiliki kaum waria di kompleks pasar Tanete yang melihat menjadi waria merupakan takdir dalam kehidupan sosialnya. Kaum waria di Tanete percaya bahwa dengan menjadi waria adalah cara mereka untuk memenuhi kebutuhan aktualisasi diri di masyarakat. Dan hal ini berdampak akan lahir generasi waria-waria berikutnya disebabkan menjadi waria sudah menjadi kebiasaan dan bagian dari keseharian masyarakat. Kebanyakan dari mereka berpendapat bahwa mereka menjadi waria karena tidak mampu membohongi kata hati, tidak mampu mengendalikan nalurinya dan tidak mampu mengelola hasrat seksual dengan baik.Hal ini membuktikan bahwa perubahan identitas yang dialami para waria yang ada di Kecamatan Bulukumpa adalah perkara yang dianggapnya sebagai takdir.dan pada akhirnya mereka kecewa dengan identitasnya sebagai laki-laki, sehingga mereka berusaha mencari solusi yang dianggapnya bisa mendapatkan keuntungan bagi dirinya yakni dengan menjadi waria. Menjadi waria memang merupakan fenomena yang lumrah dalam masyarakat setempat, dimana dari data yang didapat peneliti dari ketua waria Bulukumba Utara mengatakan bahwa penyebaran waria di Kecamatan Bulukumpa sudah mencapai kurang lebih 80 orang, hal ini menunjukkan bahwa perubahan identitas menjadi waria dari tahun ke tahun mengalami kenaikan. Itu artinya bahwa kegiatan merubah identitas sudah menjadi kegiatan yang lumrah, mereka percaya bahwa menjadi waria adalah takdir dimana mereka diciptakan sebagai lak-laki tetapi hasrat dan perasaan menyerupai 
perempuan. Dan ini yang mematikan proses berfikir mereka sehingga, dalam pengenalan terhadap identitas mereka gagal memahami kondisi psikisnya, mereka kehilangan kepercayaan diri sebagai laki-laki dan tidak mampu membawa identitasnya sebagai lakilaki dalam lingkungan sosial dimana ia berada. Ditambah lagi pendapat dari masyarakat bahwa menjadi waria memang sudah tercermin dari kehidupan masa kanak-kanak, sehingga upaya untuk membenarkan perkataan takdir dikalangan waria semakin memberi harapan kepada waria lain untuk terjun dalam dunia transgender.

Faktor-faktor yang melatarbelakangi lahirnya identitas waria pada masyarakat Bulukumba, yaitu :

\section{1) Faktor Keluarga}

Proses pembentukan identitas kaum waria sangat dipengaruhi oleh faktor keluarga, dimana seorang anak yang baru lahir mengalami proses sosialisai yang paling pertama adalah di dalam keluarga. Dari sinilah anak pertama kali mengenal lingkungan sosial dan budayanya, juga mengenal seluruh anggota keluarganya, ayah, ibu dan saudara-saudaranya sampai akhirnya anak itu mengenal dirinya sendiri. Dalam pembentukan sikap dan kepribadian anak sangat dipengaruhi oleh bagaimana cara dan corak orang tua dalam memberikan pendidikan kepada anak-anaknya, baik melalui kebiasaan, teguran, nasihat, perintah atau larangan. Termasuk didalamnya bagaimana seorang anak menemukan identitas dan jati dirinya, terbukti dari hasil penelitian bahwa salah satu factor yang menyebabkan terbentuknya identitas menjadi waria adalah faktor keluarga, dimana dari hasil penelitian ini bahwa orang tua yang cenderung memperlakukan anak laki-laki seperti anak perempuan maka sang anak besar kemungkinan akan menyukai hal-hal yang di pakai oleh perempuan, apalagi kedekatan seorang anak dengan ibu itu lebih besar dari seorang ayah. Anak laki-laki akan kehilangan panutan dari seorang ayahnya sebagai pemimpin dalam rumah tangga.

2) Faktor Lingkungan Sosial Budaya

Identitas waria terbentuk karena terbukanya ruang bagi siapa saja untuk memasuki identitas tersebut. Artinya keadaan masyarakat sekitar yang sudah menjadikan waria sebagai partner dalam menjaga kelestarian budaya, sehingga kepercayaan dengan waria itu sama posisinya dengan pemangkut adat setempat. Dalam acara pesta perkawinan misalanya waria sangat memegang peranan penting dan posisi yang sangat tinggi dalam menjalankan segala kegiatan dalam acara pesta, karena harus menjabat sebagai indo' botting artinya (Ibu pengantin) orang yang mengurus segala kebutuhan dari mempelai. Ditambah dengan acara khusus untuk para waria yang disediakan tuan rumah 
dengan berbagai kontes yang hadiahnya juga disediakan oleh yang punya pesta. Masyarakat di Kecamatan Bulukumpa berkeyakinan dengan adanya Waria, acara pesta akan semakin hidup dan semarak. Hal inilah yang membuat banyak pria tertarik untuk memasuki identitas menjadi waria, meskipun kondisi fisik psikis yang normal tidak ada kelainan seks dalam dirinya namun karena terbukanya ruang yang begitu menjanjikan sehingga jalan untuk menuju kesana semakin terbuka lebar.Hal ini tidak lepas dari peran waria itu sendiri yang telah berhasil mendapatkan kepercayaan dari masyarakat lewat karya dan kreativitasnya.

Hal ini sesuai dengan pernyataan teori yang mendukung yakni teori identitas sosial, dimana teori identitas sosial mengatakan bahwa seorang individu tidaklah dianggap sebagai individu secara mutlak satu dalam kehidupannya.Individu merupakan bagian dari kelompok tertentu baik disadari maupun tidak disadari. Konsep identitas sosial adalah bagaimana seseorang itu secara sosial dapat didefenisikan.Olehya itu, dalam proses pencarian identitas, waria sangat dipengaruhi oleh kehadiran orang lain disekitarnya, dimana mereka bersosialisai untuk memperkenalkan pribadi yang baru kepada orang lain, sehingga orang lain akan menilai dan memberikan identitas baru dalam dirinya sesuai dengan bentuk prilaku mereka. Para waria ini senang dengan identitasnya karena merasa sebagai tempat untuk mengaktualisasikan diri dan juga sebagai bentuk partisipasi terhadap masyarakat dalam menjaga kelestarian budaya.

\section{KESIMPULAN}

1) Identitas diri

Identitas waria terbentuk karena dengan menjadi waria merupakan cara yang paling tepat untuk memperkenalkan diri mereka kepada lingkungan sosialnya. Dalam hal ini, pamor menjadi waria merupakan media yang paling ampuh dalam menyampaikan pesan (isi hati yang terpendam) untuk diketahui orang lain secara sengaja. Dimana sesorang yang menjadi waria akan terbebas dari pekerjaan-pekerjaan yang sifatnya kasar dan menguras tenaga, serta sebagai ajang didalam meniti karier yang lebih baik. Upaya untuk memahami diri didapat dari proses identifikasi diri dengan orang lain. Kemudian yang kedua adalah sifat-sifat tertentu dari kaum waria di kompleks pasar Tanete yang melihat menjadi waria merupakan takdir dalam kehidupan sosialnya.

2) Identitas Kelompok

Proses pembentukan identitas kelompok waria diawali dengan adanya rasa upaya untuk melindungi diri serta melestarikan keberlangsungan hidup identitas kelompoknya, 
dimana mereka merasa bahwa dengan adanya identitas kelompok yang mereka dirikan akan semakin membantu didalam mencapai tujuan yang mereka impikan. Dalam identitas kelompok mereka bersosialisasi dengan sesama waria dalam persoalan-persoalan yang mereka hadapi, sehingga setiap persoalan mampu dipecahkan secara musyawarah.

\section{DAFTAR PUSTAKA}

Basrowi, Suwandi. (2008). Memahami Penelitian Kualitatif. Jakarta: Rineka cipta

David cavallaro, (2004) Critical and Cultural Theory, terj. Laily Rahmawati, Yogya: Niagara,

Erik H. Erikson (1989), Identitas dan siklus hidup manusia, Terjemahan Agus Cremes, Jakarta: Gramedia,

FKIP Unismuh Makassar, (2014). Pedoman penulisan skripsi, Makassar: edisi Revisi, Panrita press.

George Boeree, (2004) Personality Theories, terj. Inyiak Ridwan Muzir, Yogya: Primasophie,

Herdiansyah, Haris, (2010). Metodologi Penelitian Kualitatif Untuk Ilmu-ilmuSosial. Jakarta: Salemba Humanika.

Husserl, Edmund, (2001), The Idea of Phenomendogg, Vol. VIII, terjemahan lee hardy. Boston: Kluwer Academic publisher.

Kurniawati, M. (2003), Latar Belakang Kehidupan Laki-laki yang menjadi Waria, skripsi sarjana strata I ( tidak diterbitkan). Surabaya: Fakultas Psikologi Universita Surabaya.

Michael A. Hogg, Dominic Abrams, (1990) .Social Identification, london and New York: Routladge,

Moleong, J Lexy, (2009). Metode penelitian kualitatif. Bandung; PT Remaja Rosdakarya.

Perroto, R.S., dan Culkin, J. (1993), Exploring Abnormal Psycologi. New York: Harpercollius College Publisher.

Ritzer, George \& douglas J. Goodman, (2004), .Teori Sosiologi Modern, Jakarta: Kencana Prenada Media Group.

Santrock, J.W. (2002). Life span Deveelopment. Jilid 1 (terjemahan Achmed Chosari dan Juda damanik). Jakarta: Erlangga.

Soekanto, Soerjono. (2007). Sosiologi Suatu Pengantar. Jakarta: PT Raja Grafindo Persada. 
Sugiono. (2009). Metode Penelitian Kualitatif, Kualitatif dan R\&B. Bandung: Alfabeta Suharsimi. (1992), Prosedur penelitian. Rineka cipta: Jakarta. 